placed in fuchsine dye and subjected to a pressure of two thousand pounds per square inch for twenty-four hours. They are then removed, carefully dried, and broken to find out whether there is 'penetration' or not. If any is noticed, the representative batch of insulators is destroyed. The thermal test consists in immersing the porcelain in boiling water and then in iced water for periods of ten minutes, one hot and one cold test constituting a thermal cycle. After five such cycles, the porcelain is flashed over to test for thermal failure. After further thermal cycles, the insulators are subjected to a flashover test. They are next subjected to a flashover test at a frequency of 250,000 cycles per second. This test has proved a boon to the industry, as it eliminates porcelain with dielectric defects. In assembling the insulators, Portland cement with a definite proportion of pure water is used. They are allowed to stand five days before being cleaned and treated with weather-proofing compound, and after three more days a routine tension test is applied. The final tests are made in the presence of the customers' inspector, who sees the large completed insulator subjected to a load of $10,000 \mathrm{lb}$. weight and to a highfrequency flashover.

\section{The Census of India}

IN a paper read to the Royal Society of Arts on June 3, Dr. J. H. Hutton discussed some of the figures of the Indian census of 1931. Perfect accuracy in enumeration is not to be expected, and in this census there were certain unusual difficulties. From estimates based on those regions where the census was known to be incomplete for reasons that can be traced, it may be assumed that the deficiency for the whole of India is not more than one per mille. It was calculated that the normal increase in the decade 1921-31 should have been 8 per cent, or rather less if allowance were made for the last influenza epidemic and its inroads on population of the reproducing age. The actual increase, however, proved to be $10 \cdot 6$ per cent, a rate exceeding any previous record. The increase was greatest in the Native States and apparently has been most marked in the less fertile parts of the country, which is an indication of the pressure on agricultural land. In some cases, heavy increases have been due to an extension of irrigation. The lowest density came from certain districts of Baluchistan and the highest from part of Cochin, where the density exceeds even that of Java. There has been little change in the general proportion of urban to rural population. In 1931 the total percentage of urban population was $11 \cdot 0$ per cent as compared with $10 \cdot 2$ per cent in 1921 . The proportion of females to males is falling and is now 940 females to every 1000 males.

\section{Announcements}

THE Medical Research Council has appointed Mr. Ermest Bevin, Dr. C. G. Douglas, and Mr. W. S. Morrison, M.P., to be members of the Industrial Health Research Board in succession to Mr. Arthur Pugh, Prof. E. P. Catheart, and Major A. G. Church, who retire by rota on Sept. 30 .
AT the quarterly comitia of the Royal College of Physicians of London held on July 28, the Bisset Hawkins Gold Medal was awarded to Dr. T. H. C. Stevenson for his work as superintendent of statistics in the office of the Registrar-General. It was also announced that the Harveian Oration will be delivered by Sir George Newman, Chief Medical Officer of the Ministry of Health and Board of Education, on Oct. 18.

AT a meeting of the Council of the North-East Coast Institution of Engineers and Shipbuilders, held on July 22, the following medals were awarded: the Engineering Gold Medal to Messrs. L. J. Le Mesurier and R. Stansfield, for a paper entitled " Combustion in Heavy Oil Engines "; the Shipbuilding Gold Medal to Dr. F. H. Todd, for a paper entitled "Some Measurements of Ship Vibration"; the Thomas Fenwick Reed Medal, "for ability to take a share in the control of industry ", to Mr. W. Spencer Paulin. The first Andrew Laing Memorial Lecture of the Institution will be delivered on Oct. 28, by Eng. ViceAdmiral Sir R. W. Skelton, Engineer-in-Chief of the Fleet.

IT was announced at the annual meeting of the Wiltshire Archæological Society, which was held at Malmesbury on July 26, that the outgoing president, Mrs. M. E. Cunnington, in conjunction with her husband, Capt. B. H. Cunnington, had offered the nation the now famous prehistoric sites of Woodhenge, near Stonehenge, and the Sanctuary, near Avebury. These sites were purchased and excavated by Capt. and Mrs. Cunnington after their discovery from the air. They have since been fenced and the ring of post holes, in which the wooden, and in the latter wooden and stone posts, formerly stood, marked by low concrete pillars, showing the plan of the monuments. This generous offer has been accepted by the Office of Works.

Applications are invited for the following appoint. ments, on or before the dates mentioned:-An assistant lecturer and demonstrator in civil engineering at the University College of South Wales and Monmouthshire, Cardiff-The Registrar (Aug. 8). An assistant for abstracting scientific and technical papers at the Department of Scientific and Industrial Research, 16 Old Queen Street, S.W.1.-The Secretary (Aug. 8). An assistant engineer in the Harbour Engineer's Department, Colombo Port Commission, Ceylon-The Crown Agents for the Colonies, 4 Millbank, Westminster, S.W.1 (Aug. 8). A curator at the Art Gallery and Museum, Doncaster-The Town Clerk, Town Clerk's Office, Doncaster (Aug. 9). Junior scientific officers in the Scientific Research Pool, Air Ministry-The Chief Superintendent, Royal Aircraft Establishment, South Farnborough, Hants (Aug. 18). An engineering assistant for the Portsmouth Water Company-The Engineer, Water Company's Office, 26 Commercial Road, Portsmouth (Aug. 22). A principal at the Kadoorie Jewish Agricultural School, Mount Tabor, Palestine-The Chief Secretary to the Government of Palestine, Jerusalem (Aug. 30). 